\title{
Analysis and Classification of Volcanic Eruptions
}

\author{
Jithamala Caldera and S. C. Wirasinghe \\ Department of Civil Engineering, University of Calgary
}

\begin{abstract}
Among natural disasters, volcanic eruptions are some of the most dangerous. The severity level of the most extreme volcanic eruption for which data is available can be categorized as Catastrophe Type II according to the scale introduced by Wirasinghe, Caldera, Durage, and Ruwanpura, (2013). However, an unusually large eruption of a "super volcano" can even cause a partial or full extinction. Aftermaths of a major eruption, such as climate effects, tsunami, and famine, severely impacts populations. Potential severity levels of volcanic eruptions are studied. A multidimensional scale for volcanic eruptions is investigated. Intensity, fatalities, affected population, impacted region, cost of damage, and GDP per capita, are some factors that can be considered to determine the severity level. Relationships among the factors are also considered. An analysis is conducted to identify the specific factors to be considered in the multidimensional scale. The extreme values of known historical eruptions of each volcano are studied in terms of fatalities. However, the study does not consider any secondary effect caused by the volcanic eruptions. The extreme values of fatalities from eruptions of 136 volcanoes are shown to be distributed as a 3 parameter Weibull ( $\alpha=0.33925, \mu=1, \sigma=109.04)$ distribution.
\end{abstract}

\section{INTRODUCTION}

The "fire from the earth," volcano, is a crater of the earth's crust. Hot magma, hot vapour, and gasses escape through a vent when they erupt. Volcanoes have played a major role in the formation of the Earth's atmosphere, ocean, and continents throughout history. They are one of the natural disasters classified as a geophysical event (Low \& Wirtz, 2010).

Volcanoes grow by adding layers and height with the accumulation of lava or ash. They can be classified according to the level of activity as follows: active (presently erupting), dormant (not presently erupting but could at future date), and extinct (no eruptions in recorded history). In addition, volcanoes can be categorized according to their shapes and sizes, such as: compound volcanoes (complex of cones), stratovolcanoes (composite alternating layers of lava and ash), somma volcanoes (a new central cone outgrowing the original caldera), and caldera (volcanic collapse crater [Siebert, Simkin, \& Kimberly, 2011]). Special types of volcanoes are also distinguished, such as super volcanoes or hot spots. Historical evidence of super volcanoes does not currently exist; however, evidence for these massive phenomena have been observed in the geological record. Examples of some hotspots are Hawaii, Yellowstone National Park (United States), Iceland, Samoa, and Bermuda. Self (2006) has explained the possible aftermath of super volcanic eruptions: "It is more likely that the Earth will next experience a super-eruption than an impact from a large meteorite greater than $1 \mathrm{~km}$ in diameter. Depending on where the volcano is located, the effects will be felt globally or at least by a whole hemisphere".

Volcanoes are found both on land and in the ocean (i.e., seamount volcanoes). About $94 \%$ of known historical eruptions in the planet's surface are concentrated in linear belts (total length of 32,000 $\mathrm{km}$ and width of $100 \mathrm{~km}$ ) which cover less than $0.6 \%$ of the Earth's surface (Sigurdsson, Houghton, Rymer, Stix, \& McNutt, 1999). In addition, in Encyclopaedia of Volcanoes (Sigurdsson et al., 1999) claims that $80 \%$ of the world's population lives in a nation with at least one Holocene volcano (active since the end of ice age, i.e., approximately 11,700 years) and that the resources for dealing with volcanic hazards are not evenly distributed. Moreover, he noted that because of the generality of the word "active," the exact figure of the world's active volcanoes cannot be accurately identified. However, an approximate number of 1,500 historically active or Holocene volcanoes are identified on the Earth's surface. On average, 50-60 volcanoes are active each year (Natural Environment Research Council, 2005). Mauna Loa in Hawaii is the world's largest active volcano, rising 13,677 feet above sea level; its top being over 28,000 feet above the nearby depth of the ocean floor.

For the most part, volcanoes are primary disasters; however, they can also be secondary disasters when triggered by earthquakes. Volcanoes can, in turn, result in secondary disasters such as tsunamis (e.g., 1883, Krakatau in Indonesia), famines (e.g., 1815, Tambora in Indonesia), climate anomalies (e.g., 1815, Indonesia's Tambora causing June snow falls 
and crop failures in New England, US), volcano collapses (e.g., 1792, Unzen in Japan), roof collapses, disease (e.g., 1991, Pinatubo in Philippines), and ash clouds (e.g., threat to air traffic, such as great circle routes to Japan over Alaska). Also, volcano eruptions can lead to pyroclastic flows (mixtures of hot gas and ash flowing at very high speeds [e.g., 100,200 km/h] leading to extreme heat and oxygen loss), lava flows (which are slow moving but can destroy houses, roads, and other structures), pollution (emission of strong poisonous gasses such as sulfur dioxide, hydrogen chloride, and hydrogen fluoride), mudflows (e.g., 1985, Ruiz, Colombia), ash flows (e.g., 1902, Mount Pelee, Martinique), and ash falls (causes respiratory problems and coverage of houses, buildings, roads, and crops with ash, [e.g., 1991, Chile's Cerro Hudson, Argentina, and 79 A.D., Vesuvius in Italy).

The risk level of a volcano can be estimated by close monitoring. Nevertheless, the accurate estimation of volcano eruption is not currently possible, only the approximate time of eruption can be estimated through regular monitoring. The estimated time to a volcanic eruption may be given in hours, days, or can simply be a 30 second warning alarm (Wirasinghe, et.al, 2013).

Scientists measure the magnitude of eruptions by the Volcanic Explosivity Index (VEI). It is a general indicator of the explosive character of an eruption, as shown in Table 1. Newhall and Self (1982) introduced this scale, and it distinguishes any eruption in the range from 0 to 8 . Intensity (column heights), magnitude (descriptive terms), and rate of energy release during an eruption (blast durations) are considered in this scale. When developing the VEI scale, researchers identified that a quantitative or semiquantitative method for comparing eruptions was required.

\section{PROBLEM STATEMENT}

To predict severity levels of volcanic eruptions by utilizing available resources and technology, an understanding of the mechanisms involved with volcanism is essential. The volcanism of a certain region is characterized based on its history; therefore, it is necessary to document its full breadth. Unless eruptions are documented at the time of their occurrence, essential data required for prediction may be lost (Siebert, et al., 2011). At present, the number of reported eruptions is increasing as compared to the past; however, in general, records are incomplete. A few historical reports contain some, but not all, of the necessary data; most contain only a brief and often ambiguous description of the eruptions (Newhall \& Self, 1982). Volcanoes of the World (Simkin, Siebert, McClelland, Bridge, Newhall, \& Latter, 1981) has significantly contributed
Table 1. Volcanic Explosivity Index (VEI) criteria (Newhall \& Self, 1982). Source: Table 8 from Siebert, et.al., 2011

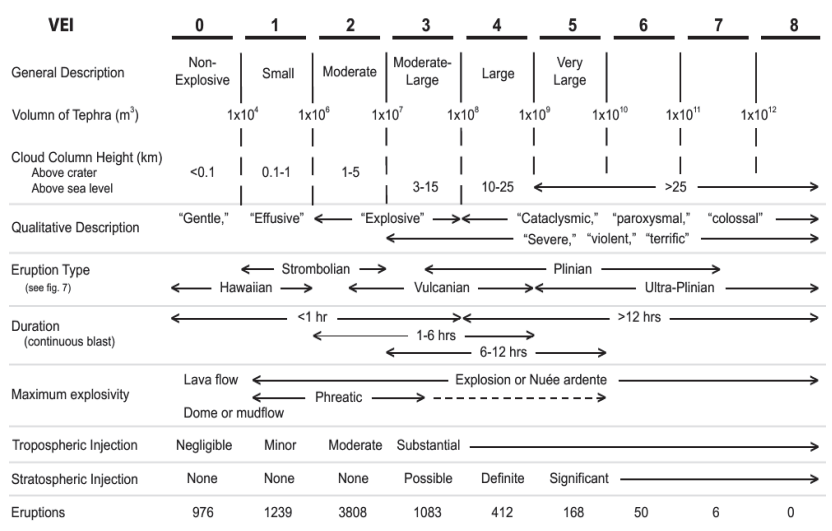

to the understanding of the classification of past volcanic events by using the VEI scale on existing historical records. However, it was noted that the VEI was inadequate with respect to some aspects of disaster classification, for example, the climate effect.

Moreover, the same disaster can be interpreted by several terms, according to the writer's knowledge, experience, and personal feelings towards the disaster. Several researchers have identified this as a major problem. Volcanology, unfortunately, has no instrumentally determined magnitude scale, like that used by seismologists for earthquakes, and it is easy to understand why one observer's "major" eruption might be another's "moderate" or even "small" event (Siebert et.al., 2011).

Therefore, it is not uncommon for numerous records to exist for the same event, sometimes with differing conclusions. For example, the 1815 eruption of Mount Tombora in Indonesia has different fatality records in different sources. "Victims from Volcanic Eruptions: A Revised Database" (Tanguy, Ribière, Scarth, \& Tjetjep, 1998) recorded the direct volcanic effect fatalities as 11,000 (and other posteruption famine and epidemic disease causing 49,000 fatalities). But it is given as 10,000 volcanic fatalities $(117,000$ total fatalities) in the National Oceanic and Atmospheric Administration (NOAA) database. Furthermore, the EM-DAT database records the eruption of the Martinique Volcanic eruption on May 8,1902 , as the most deadly volcanic event with 30,000 fatalities. However, the NOAA database records the same event with 28,000 fatalities. This may be true for several reasons. Either some historic records may not be accurate or the disaster may be interpreted in different ways. For instance, one can count fatalities resulting directly from the volcano, or one can consider fatalities as a result of the aftermath as well (e.g., secondary disasters such as starvation). Similarly, according to the EM-DAT database, the Colombian eruption in 1985 resulted in the highest economic losses at around US $\$ 1$ billion. 
Whereas NOAA cites the highest economic losses due to a volcanic eruption to be the 1980 Mount Saint Helen eruption in Washington, US, at US \$2 billion. This is another example of inconsistency among databases.

Although historical inaccuracy of past records is unavoidable, there should be a focus for avoiding inaccuracies in the future. Hence, consistent interpretation (primary/secondary disaster), proper scale, good understanding of volcanoes, and an expanded recording system are required to accomplish this goal.

The largest eruption might not be the most deadly eruption for several reasons. Other eruptions may have been as big as or bigger than the deadliest. For instance, current larger human populations than ever before may increase the number of fatalities. On the other hand, education levels of local residents about the disaster, existing technology, and available recourses may decrease the number of fatalities.

Table 2. Disaster scope

\begin{tabular}{ccccc}
\hline Scope & Disaster & $\begin{array}{c}\text { Casualties } \\
\text { (persons) }\end{array}$ & $\begin{array}{c}\text { Area Affected } \\
\left(\mathbf{K m}^{2}\right)\end{array}$ \\
\hline I & Small & $<10$ & or & $<1$ \\
\hline II & Medium & $10-100$ & or & $1-10$ \\
\hline III & Large & $100-1,000$ & or & $10-100$ \\
\hline IV & Enormous & $1,000-10,000$ & or & $100-1,000$ \\
\hline V & Gargantuan & $>10,000$ & or & $>1,000$ \\
\hline
\end{tabular}

Table 3. Fatality (F)-based disaster scale

\begin{tabular}{|c|c|c|}
\hline Type & $\begin{array}{l}\text { Fatality } \\
\text { Range }\end{array}$ & Example \\
\hline Emergency & $1 \leq F<10$ & A small landslide that kills one person \\
\hline $\begin{array}{l}\text { Disaster } \\
\text { Type } 1\end{array}$ & $\begin{array}{l}10 \leq F \\
<100\end{array}$ & $\begin{array}{l}\text { Edmonton tornado, Canada }-1987 \\
\text { that killed } 27 \text { people }\end{array}$ \\
\hline $\begin{array}{l}\text { Disaster } \\
\text { Type } 2 \\
\end{array}$ & $\begin{array}{l}100 \leq F \\
<1,000\end{array}$ & $\begin{array}{l}\text { Thailand flood-2011 that resulted in a } \\
\text { total of } 815 \text { deaths }\end{array}$ \\
\hline $\begin{array}{l}\text { Catastrophe } \\
\text { Type } 1 \\
\end{array}$ & $\begin{array}{l}1,000 \leq \mathrm{F} \\
<10,000\end{array}$ & $\begin{array}{l}\text { Hurricane Katrina-2005, U.S.A that } \\
\text { killed } 1833 \text { people }\end{array}$ \\
\hline $\begin{array}{l}\text { Catastrophe } \\
\text { Type } 2\end{array}$ & $\begin{array}{l}10,000 \leq F \\
<100,000\end{array}$ & $\begin{array}{l}\text { Tohuku earthquake and tsunami- } \\
\text { 2011, Japan that killed } 15882 \text { people }\end{array}$ \\
\hline $\begin{array}{l}\text { Calamity } \\
\text { Type } 1\end{array}$ & $\begin{array}{l}100,000 \\
\leq \mathrm{F}<1 \mathrm{M}\end{array}$ & $\begin{array}{l}\text { Haiti earthquake } 2010 \text { killed } 316,000 \\
\text { people }\end{array}$ \\
\hline $\begin{array}{l}\text { Calamity } \\
\text { Type } 2 \\
\end{array}$ & $\begin{array}{l}1 \mathrm{M} \leq \mathrm{F} \\
<10 \mathrm{M}\end{array}$ & $\begin{array}{l}\text { China floods-1931 death toll } \\
>2,500,000\end{array}$ \\
\hline $\begin{array}{l}\text { Cataclysm } \\
\text { Type } 1\end{array}$ & $\begin{array}{l}10 M \leq F \\
<100 M\end{array}$ & - \\
\hline \multirow{2}{*}{$\begin{array}{l}\text { Cataclysm } \\
\text { Type } 2\end{array}$} & \multirow{2}{*}{$\begin{array}{c}100 \mathrm{M} \leq \mathrm{F} \\
<1 \mathrm{~B}\end{array}$} & Super Volcano (e.g. Yellowstone) \\
\hline & & Estimated deaths <1B \\
\hline \multirow{2}{*}{$\begin{array}{l}\text { Partial or } \\
\text { Full } \\
\text { Extinction }\end{array}$} & \multirow{2}{*}{$\begin{array}{l}1 \mathrm{~B} \leq \mathrm{F} \\
<10 \mathrm{~B}\end{array}$} & $\begin{array}{c}\text { Meteor strike (diameter }>1.5 \mathrm{Km} \text { ) - } \\
\text { estimated deaths }:<1.5^{\star} 109\end{array}$ \\
\hline & & $\begin{array}{l}\text { Pandemic (Avian influenza) - } \\
\text { estimated deaths : <2.8B }\end{array}$ \\
\hline
\end{tabular}

With an increase in research and better early prediction technology, early warning systems and hazard mitigation can also reduce the destructive capacity of the eruption.

Different scales have been introduced to distinguish the destructive capacity of a disaster. Disaster scope (Gad-El-Hak, 2008) is an example of a disaster scale for all types of disasters. Five levels (from Scope 1 to 5 ) differentiate the severity of a disaster. Scopes are determined according to the number of casualties and/or geographic area affected. Table 2 illustrates the disaster scope. The ranges proposed for casualties and the area affected appear to be arbitrary.

The fatality-based disaster scale (Wirasinghe et al., 2013) is another classification of natural disasters. Table 3 shows the fatality-based disaster scale which has categories using commonly used terminologies that describe various magnitudes. This scale has been developed largely on the basis of fatality statistics.

The question is whether these scales can clearly distinguish the severity levels of a disaster. Still, there is no right answer to this question because there are a lot of factors that need to be considered when addressing the severity. However, lack of data prevents such sophisticated scale. If there is more information available, a more advanced scale can be introduced. But to have good data, a better recording system and a more informative database is needed. To have a better database, more precise terminology and a good scale are useful.

In this paper, potential severity levels of volcanic eruptions are examined using available data. As discussed in the previous paragraph, the lack of data reduces the extent of the analysis. In total, 652 volcanic eruptions from 4360 B.C. to 2014 A.D. (February 1) obtained from the NOAA database for both volcanic effects and total effects (volcano, tsunami, earthquake, etc.) are considered. Five factors-number of fatalities, injuries, houses damaged, missing people, and damage (in million dollars)-have been studied. Data are available as numeric values and an interval variable (ordered categories) for each factor. Although there are 652 recorded volcanic eruptions, all eruptions have no data value for at least two numerical variables. Ordinal interval variables have more data values compared to the corresponding individual numeric values; hence, the analysis is done using the interval variable.

\section{PARAMETERS THAT REFLECT THE SEVERITY OF A VOLCANIC EVENT}

This section is focused on identification of the parameters that reflect the severity of volcanic 
eruptions. Intensity, fatalities, affected population, impacted region, cost of damage, and GDP per capita are some initial factors that could be considered to determine the severity levels. However, lack of historical data has limited the analysis. Volcanic eruptions are measured using the VEI scale (0 to 8) which is an ordinal categorical variable. VEI is the best currently available factor that distinguishes one eruption from the other. Thus the VEI scale is used to find the relationships between severity levels and other impact factors. The SPSS software is used for the analysis using ordinal logistic regression.

All factors considered are ordinal variables; therefore, spearman's rho correlation coefficient $(\rho)$ is used to observe the correlation. Each ordinal interval variable for "direct volcanic effects" shows an excellent linear relationship with the corresponding variable for "total effects" with $\rho>0.9$ for all pairs. Thus, direct volcanic effects alone can be used to explain the relationship with other factors.

Lack of data highly influenced the model selection even within the volcano effects. All except one eruption, from 652 that are recorded, are missing one or more data for categorical variable. The VEI scale is not defined for 90 eruptions. Correlation amongst the volcanic impact variables has been observed. Damage in millions of dollars has a very good linear relationship with houses damaged $(\rho=$ 0.9 ). One variable stayed in the model while the other is omitted because of the high correlation. Damage in millions of dollars has a close relationship with time and inflation, and, thus, is hard to estimate. Hence, it is omitted from the model. The number of missing people and number of deaths are also highly correlated $(\rho=0.9)$. It can be observed that the number of pair wise data is fairly low with presence of the number of missing people. It may explain the higher $\rho$ value for some pairs. Therefore, the number of missing people is also omitted from the model. Other pairs, for example, deaths and houses damaged, are not highly correlated but have a moderate to good relationship $(0.5 \leq \rho<0.75)$.

Different approaches have been tried to select a good relationship between $\mathrm{VEI}$ and the other variables. Some of the approaches are:

- Different link function (logit, probit, etc.)

- Log transformation of death, house, injuries

- Different periods

- Last 32 years (after 1982), after the VEI scale is introduced

- Last 114 years, after 1900

- Last 514 years, after 1500
- Include interaction terms to the model (to address the multicollinearity effect)
- Death*houses
○ Death*injuries
○ Houses*injuries

- VEI grouping (lack of data in lower and higher levels of VEI)

$$
\begin{aligned}
& \circ \operatorname{VEI}(6,7,8->5) \\
& \circ \operatorname{VEI}(0,1->1)(5,6,7,8->5)
\end{aligned}
$$

Link Function for logit model:

$$
\begin{gathered}
\log \left(\frac{\text { ProbabilityofVEI } \leq \mathrm{j}}{\text { ProbabilityofVEI }>\mathrm{j}}\right)=\alpha+\beta \mathrm{x} ; \\
\text { where } \mathrm{j}=1,2,3,4,5 .
\end{gathered}
$$

Ordinal interval variables of death, injuries, and houses damaged individually have formed a good ordinal regression model with VEI. The best models are given when the link function is logit, as shown in the above equation, that is, with the assumption that the residuals are logistically distributed and VEI is grouped (VEI 0,1 as VEI 1 and VEI 5,6,7,8 as VEI 5). Therefore, the best selected models are death, injuries, and houses damaged individually with grouped VEI scale. All the p-values corresponding to the estimated parameters are less than 0.1 in these models. The estimated values represent the parameters $\alpha$ (threshold) and $\beta$ (location) in the above equation with a $90 \%$ confidence level. In ordinal logistic regression, it is assumed that each level of VEI is parallel to the other. To select the best models, the following hypothesis tests have been conducted with $95 \%$ confidence level:

- Tests of parallel lines

- Goodness of fit tests

- Overall model fits

The models also improved when testing the data only for the last 114 years, though the combination of VEI grouping and data for the last 114 years is not an improvement. The lack of data was felt again when testing the model for the last 32 years. The accuracy of the assigned VEI scale for volcanic eruptions could have been tested through this approach if sufficient data existed. Moreover, one variable becomes significant with the presence of another variable because of multicollinearity between two variables (e.g., injuries become significant with the presence of deaths, houses become significant with the presence of deaths and houses become significant with the presence of injuries). The multicollinearity effect remains the same for all applied approaches; hence, the 
combination of several impact variables could not be achieved as expected.

The results highlight the fact that individual variables of death, injuries, and number of houses damaged are better than the combinations of the above variables in explaining the relationship with VEI. In other words, the use of "or" between the variables is better than the use of "and" when describing the relationship between severity of the volcanic eruptions and the above concerned variables. Only the number of fatalities has been discussed in the following section out of the number of houses damaged and number of people injured.

\section{SEVIRITY LEVEL BOUNDARIES}

This section examined how the severity levels are spread with the number of fatalities, specifically the intervals or ranges or boundaries of fatalities which differentiate one severity level from the other.

There are 236 volcanoes in the NOAA database which have at least one eruption. For extreme value data analysis, only the maximum fatality recorded for different volcanoes is considered. For instance, in the volcanic effects for the Mount Tombora 1815 eruption record 10,000 , Mount Krakatoa 1883 eruption record 2,000, etc. Likewise the maximum fatality records for different volcanoes are selected. All other records for Mount Krakatoa except the 1883 eruptions are not considered. All the records which do not have at least one fatality are also not considered because the cells which are blank in the database either represent no fatality or no record found. Then, extreme fatality recorded eruptions for 136 volcanoes are shown to be distributed as a 3 parameter Weibull ( $\alpha=0.33925, \mu=1, \sigma=109.04$ ) distribution with a sample mean of $1,202.81$, a sample variance of $4,251.75$, and a maximum of 30,000 . Other extreme value distributions give unrealistic values. Figure 1 shows the histogram of the extreme fatality volcano effects and the fitted Weibull (3P) density (dashed line).

The considered dataset of volcanic effects followed the fatality-based disaster scale for all types of natural disasters (Wirasinghe et al., 2013). According to the fitted Weibull distribution for volcanic eruptions, $35 \%$ of the eruptions are Emergency type; $27 \%$ and $26 \%$ of eruptions are Disaster Type 1 and 2 , respectively; and $11 \%$ and $1 \%$ of eruptions are Catastrophe Type 1 and 2, respectively. Wirasinghe et. al. (2013) stated that volcanic eruptions go up to Catastrophe Type 2 level. However, four in 100,000 eruptions have the ability to reach the Calamity Type 1 , according to the fitted Weibull (3P) distribution, though there is no evidence in recorded history. The severity level of the most extreme volcanic eruption for which data is available (450 A.D., llopango, El Salvador, 30,000 fatalities) can be categorized as
Catastrophe Type 2. Table 5 shows the fatality-based disaster scale for some volcanic eruptions. Volcanic eruptions can vary from Emergency to the Calamity Type 1 level. However, an unusually large (super

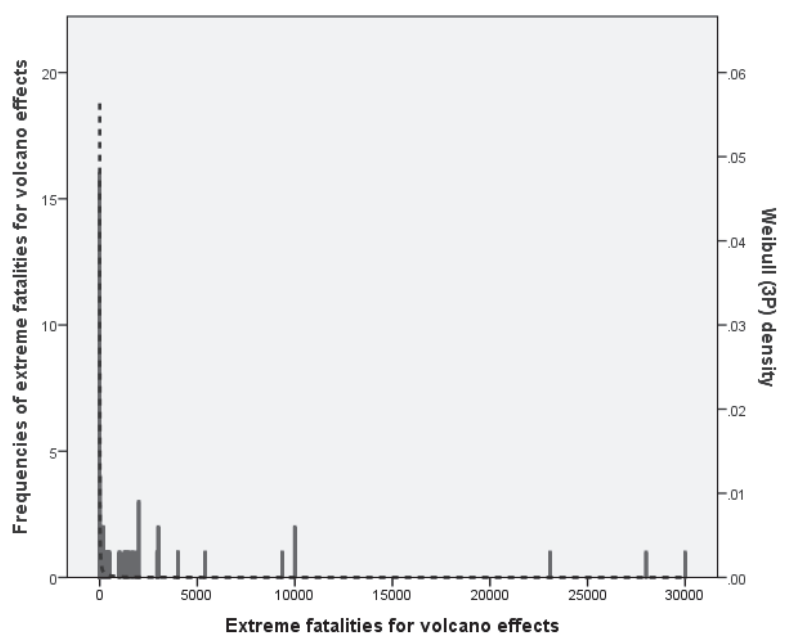

Figure 1. Histogram of extreme fatalities for volcano effects and the fitted Weibull (3P) density (dash line)

Table 4. Probability of an eruption to be of the given type

\begin{tabular}{|c|c|c|}
\hline Type & Fatality Range & Probability \\
\hline Emergency & $1 \leq F<10$ & 0.348852 \\
\hline Disaster Type 1 & $10 \leq F<100$ & 0.271215 \\
\hline Disaster Type 2 & $100 \leq F<1,000$ & 0.259911 \\
\hline Catastrophe Type 1 & $\begin{array}{c}1,000 \leq \mathrm{F}< \\
10,000\end{array}$ & 0.110283 \\
\hline Catastrophe Type 2 & $\begin{array}{c}10,000 \leq \mathrm{F}< \\
100,000\end{array}$ & 0.009699 \\
\hline Calamity Type 1 & $\begin{array}{c}100,000 \leq F< \\
1 \mathrm{M}\end{array}$ & 0.000040 \\
\hline Calamity Type 2 & $1 \mathrm{M} \leq \mathrm{F}<10 \mathrm{M}$ & 0 \\
\hline Cataclysm Type 1 & $10 M \leq F<100 M$ & 0 \\
\hline Cataclysm Type 2 & $100 M \leq F<1 B$ & 0 \\
\hline $\begin{array}{l}\text { Partial or Full } \\
\text { Extinction }\end{array}$ & $1 \mathrm{~B} \leq \mathrm{F}<10 \mathrm{~B}$ & 0 \\
\hline
\end{tabular}

Table 5. Fatality-based disaster scale for volcano

\begin{tabular}{ccccc}
\hline \multirow{2}{*}{ Type } & \multicolumn{4}{c}{ Example } \\
\cline { 2 - 5 } & Year & Volcano & Country & Fatalities \\
\hline Emergency & 2011 & Nabro & Eritrea & 7 \\
\hline $\begin{array}{c}\text { Disaster } \\
\text { Type 1 }\end{array}$ & 1975 & Marapi & Indonesia & 80 \\
\hline $\begin{array}{c}\text { Disaster } \\
\text { Type 2 }\end{array}$ & 1991 & Pinatubo & Philippines & 450 \\
\hline $\begin{array}{c}\text { Catastrophe } \\
\text { Type 1 }\end{array}$ & 1951 & Lamington & $\begin{array}{c}\text { Papua } \\
\text { New }\end{array}$ & 2942 \\
\hline $\begin{array}{c}\text { Catastrophe } \\
\text { Type 2 }\end{array}$ & 1985 & Ruiz & Colombia & 23080 \\
\hline
\end{tabular}


volcanic) eruption has the potential to exceed the above mentioned levels. They can cause a calamity or even a partial or full extinction.

\section{CONCLUSION}

This paper presents the initial attempts to develop a multidimensional scale for volcanic eruptions. The analysis is limited to five variables: number of fatalities, number of missing people, number of injuries, number of houses damaged, and damage in million dollars. Extensions of this work are expected to be reported in future.

\section{REFERENCES}

Centre for Research on the Epidemiology of Disasters. (n.d.). EM-DAT: The international disaster database. Retrieved from http://www.emdat.be/database

Gad-El-Hak, M. (2008). The art and science of largescale disasters. In M. Gad-El-Hak (Ed.), Largescale disasters (pp. 5-68). New York, NY: Cambridge University Press.

Low, P., \& Wirtz, A. (June 2010). Structure and needs of global loss databases about natural disaster. Paper presented at the IRDC Davos 2010: Third International Disaster and Risk Conference, Davos, Switzerland.

National Geophysical Data Center. (n.d.). Volcano events search [Data file]. Available from http://www.ngdc.noaa.gov/hazard/

Natural Environment Research Council. (2005). Natural hazards scientific certainties and uncertainties. Swindon, UK: Natural Environment Research Council.
Newhall, C. G., \& Self, S. (1982). The volcanic explosivity index (VEI) an estimate of explosive magnitude for historical volcanism. Journal of Geophysical Research: Oceans, 87(C2), 12311238. http://dx.doi.org/10.1029/JC087iC02p01231

Self, S. (2006). The effects and consequences of very large explosive volcanic eruptions. Philosophical Transactions of the Royal Society A: Mathematical, Physical and Engineering Sciences, 364(1845), 2073-2097. http://dx.doi.org/ 10.1098/rsta.2006.1814

Siebert, L., Simkin, T., \& Kimberly, P. (2011). Volcanoes of the world (3rd ed.). Berkeley, CA: University of California Press.

Sigurdsson, H., Houghton, B., Rymer, H., Stix, J., \& McNutt, S. (1999). Encyclopaedia of volcanoes. Burlington, MA: Academic Press.

Simkin, T., Siebert, L., McClelland, L., Bridge, D., Newhall, C. G., \& Latter, J. H. (1981). Volcanoes of the world: A regional directory, gazetteer, and chronology of volcanism during the last 10,000 years. Stroudsburg, PA: Hutchinson Ross Publishing.

Tanguy, J. -C., Ribière, C., Scarth, A., \& Tjetjep, W. S. (1998). Victims from volcanic eruptions: A revised database. Bulletin of Volcanology, 60(2), 137-144. http://dx.doi.org/10.1007/s004450050222

Wirasinghe, S. C., Caldera, H. J., Durage S. W., \& Ruwanpura, J. Y. (2013). Preliminary analysis and classification of natural disasters. In Proceedings of the ninth annual conference of the International Institute for Infrastructure, Renewal and Reconstruction. Brisbane, Australia: Queensland University of Technology. 